УДК: 338.47:656.2

\title{
ПІДХОДИ ДО ВИЗНАЧЕННЯ ЕКОНОМІЧНОЇ ЕФЕКТИВНОСТІ ТЕХНІЧНИХ ЗАСОБІВ В МІСЦЯХ ПЕРЕТИНУ ТРАНСПОРТНИХ ПОТОКІВ НА ОДНОМУ РІВНІ
}

\author{
Блиндюк В.С., д.т.н., професор (УкрДУЗТ)
}

У статті розглянуто підходи до визначення економічної ефективності застосування функціонуючої або модернізованої агрегатної структури технічних засобів, якими обладнані місия перетину транспортних потоків на одному рівні, з позицій якості та безпеки транспортного обслуговування. Проведений аналіз свідчить про те, щзо проблема безпеки й якості транспортного обслуговування залізничних переїздів є надзвичайно складною та, поряд з сочіальними, має яскраво виражені економічні наслідки. Виходячи з критеріїв якості та безпеки транспортного обслуговування залізничних переїзів, запропоновано застосування агрегатного підходу до визначення економічної ефективності їх обслуговування. Його особливістю є врахування функиіонуючої або модернізованої агрегатної структури технічних засобів, якими наразі обладнані залізничні переїзди. A тому економічна оцінка якості та безпеки транспортного обслуговування місиь перетину транспортних потоків на одному рівні в умовах застосування агрегатного підходу виконується за кожним окремим пристроєм у складі технічних засобів, якими обладнанні залізничні переїзд. Вибір саме агрегатного підходу трунтується на його теоретичні та практичній цінності.

Ключові слова: економічна ефективність, технічні засоби, транспортне обслуговування, місця перетину транспортних потоків на одному рівні, агрегатний підхід, теоретична та практична цінність

\section{ПОДХОДЫ К ОПРЕДЕЛЕНИЮ ЭКОНОМИЧЕСКОЙ ЭФФЕКТИВНОСТИ ТРАНСПОРТНЫХ СРЕДСТВА В МЕСТАХ ПЕРЕСЕЧЕНИЯ ТРАНСПОРТНЫХ ПОТОКОВ НА ОДНОМ УРОВНЕ}

\author{
Блиндюк В.С., д.т.н., профессор (УкрГУЖТ)
}

В статье рассмотрены подходы к определению экономической эффективности применения функичонирующей или модернизированной агрегатной структуры технических средств, которыми оборудованы места пересечения транспортных потоков на одном уровне, с позиций качества и безопасности транспортного обслуживания. Проведенный анализ свидетельствует о том, что проблема безопасности и качества транспортного обслуживания железнодорожных переездов является чрезвычайно сложной и, наряду с социальными, имеет ярко выраженные экономические последствия. Исходя из критериев качества и безопасности транспортного обслуживания железнодорожных переездов, предложено применение агрегатного подхода к определению экономической эффективности их обслуживания. Его особенностью является учет функциионирующей или модернизированной агрегатной структуры технических средств, которыми оборудованы железнодорожные переезды. А потому экономическая оченка качества и безопасности транспортного обслуживания мест пересечения транспортных потоков на одном уровне в условиях применения агрегатного подхода выполняется по каждому отдельному устройству в составе технических средств, которыми оборудованы железнодорожные переезды. Выбор именно агрегатного подхода основывается на его теоретической и практической ценности.

Ключевые слова: экономическая эффективность, технические средства, транспортное обслуживание, места пересечения транспортных потоков на одном уровне, агрегатный подход, теоретическая и практическая ценность 


\title{
APPROACHES TO DETERMINATION OF ECONOMIC EFFECTIVENESS OF TECHNICAL MEANS IN THE PLACES OF CROSSING OF TRANSPORT STREAMS ON A SINGLE LEVEL
}

\author{
Blinduk V.S., doctor of Technical Sciences, Professor (USU of RT)
}

In article approaches to definition of economic efficiency of application functioning or upgraded (completely changed) the aggregate patterns of technical means, which are equipped with places of crossing of transport streams on one level, from the standpoint of quality and safety of transport services. The analysis shows that the problem of safety and quality of transport service of railway crossings is extremely difficult and, along with social has a pronounced economic impact. Based on the criteria of quality and safety of transport services railway crossings, the proposed application of the aggregate approach to determining the economic efficiency of their service. It is taking into account functioning or upgraded (completely changed) the aggregate structure of hardware, which is now equipped with railroad crossings. Therefore economic evaluation of the safety and quality of transport service of the intersection traffic flows at the same level in the conditions of application of the aggregate approach is performed for each individual device in the composition of technical means, which are equipped with railroad crossings. The choice of aggregation approach is based on its theoretical and practical value.

Keywords: economic efficiency, technical facilities, transportation, places of crossing of transport streams on one level, building-block approach, theoretical and practical value

Актуальність проблеми та ї̈ зв'язки 3 науковими чи практичними завданнями. Розвиток транспортного комплексу України безумовно залишається одним 3 першочергових завдань, яке потребує негайного вирішення. Його терміновість обумовлена впливом розвитку транспорту на функціонування економіки держави у цілому при тому, що від ступеня розвитку транспортної галузі залежить економічна безпека країни.

Основою транспортного комплексу України $€$ залізничний транспорт, яким виконується понад $60 \%$ вантажних і $50 \%$ пасажирських перевезень. Маючи можливості для перевезення мінерально-сировинних i паливних ресурсів, нафти та нафтопродуктів, продукції чорної та кольорової металургії у великих обсягах на дальні відстані залізничний транспорт не має значних конкурентів у виконанні цих перевезень.

Проголошення України як транзитної держави зумовлює об'єктивну необхідність розвитку технічних засобів залізничного транспорту, особливо у сфері забезпечення безпеки руху. У цьому зв'язку загострюється проблема забезпечення безпеки й якості транспортного обслуговування в місцях перетину транспортних потоків в одному рівні.

Аналіз останніх досліджень $i$ публікацій. Широке коло питань, пов'язаних 3 роботою транспортної галузі України в цілому та залізничного транспортно зокрема, а також питань щодо забезпечення ефективності його функціонування знайшли своє відображення у працях вітчизняних і зарубіжних економістів. На думку автора, особливої уваги потребують дослідження таких вчених, як: Абрамов А.П., Галабурда В.Г. [1], Волков Б.Д., Лобанова I.C [2], Гибшман А.Б. [3], Дикань В.Л., Кірдіна О.Г. [4], Івлєв І.В. [5], Міщенко С.П. [6], Пасічник В.І. [7], Чередниченко О.Ю. [8] та інші. При всій важливості та корисності виконаних досліджень, як свідчить статистика аварійності в місцях перетину транспортних потоків на одному рівні, розглянута проблеми не втратила актуальності й в цей час.

Виділення невирішених питань загальної проблеми. Не дивлячись на високий темп розвитку технічних засобів, якими наразі обладнанні залізничні переїзди, та відповідних їм технологій спроби вирішити існуючі проблеми тільки організаційно-технічними заходами не приносять бажаних результатів. Більш того, при зростанні обсягів транспортних потоків залізничні переїзди все більше перетворюються на проблемні місця у народному господарстві, виступаючими своєрідними «поглиначами» державних коштів внаслідок виникнення аварійних ситуацій, необхідності покриття збитків та подолання негативних впливів на екосистему.

Саме тому постає задача обгрунтування застосування економічних критеріїв поліпшення транспортного обслуговування місць перетину транспортних потоків на одному рівні через показники річного економічного ефекту та 
індексу прибутковості.

Мета дослідження. Таким чином, метою статті $\epsilon$ розробка та теоретичне обгрунтування економічного підходу до визначення ефективності застосування технічних засобів обладнання місць перетину транспортних потоків на одному рівні 3 позицій якості та безпеки транспортного обслуговування на залізничних переїздах.

Виклад основного матеріалу дослідження. Безпека функціонування будьякого виду транспорту на ринку транспортних послуг, у першу чергу, залежить від технічного рівня транспортного обслуговування, а потім вже від інших факторів: рівня маркетингу, рекламноінформаційного забезпечення, організації сервісу та ін. У відповідності до поставленого завдання у подальшому дослідження буде присвячено економічному обгрунтуванню заходів 3 якості та безпеки перетину транспортних потоків на одному рівні.

Рівень транспортного обслуговування на залізничних переїздах прямо пов'язаний 3 експлуатаційними характеристиками технічних засобів, якими вони обладнанні, та 3 якісними характеристиками транспортного обслуговування місць перетину транспортних потоків на одному рівні (рис. 1).

В.ластивість технічних засобів в місцях перстину транспортних потоків на одному рівні не створювати небезпеку для здоров'я та життя пасажирів, а також для збереження перевезеного вантажу

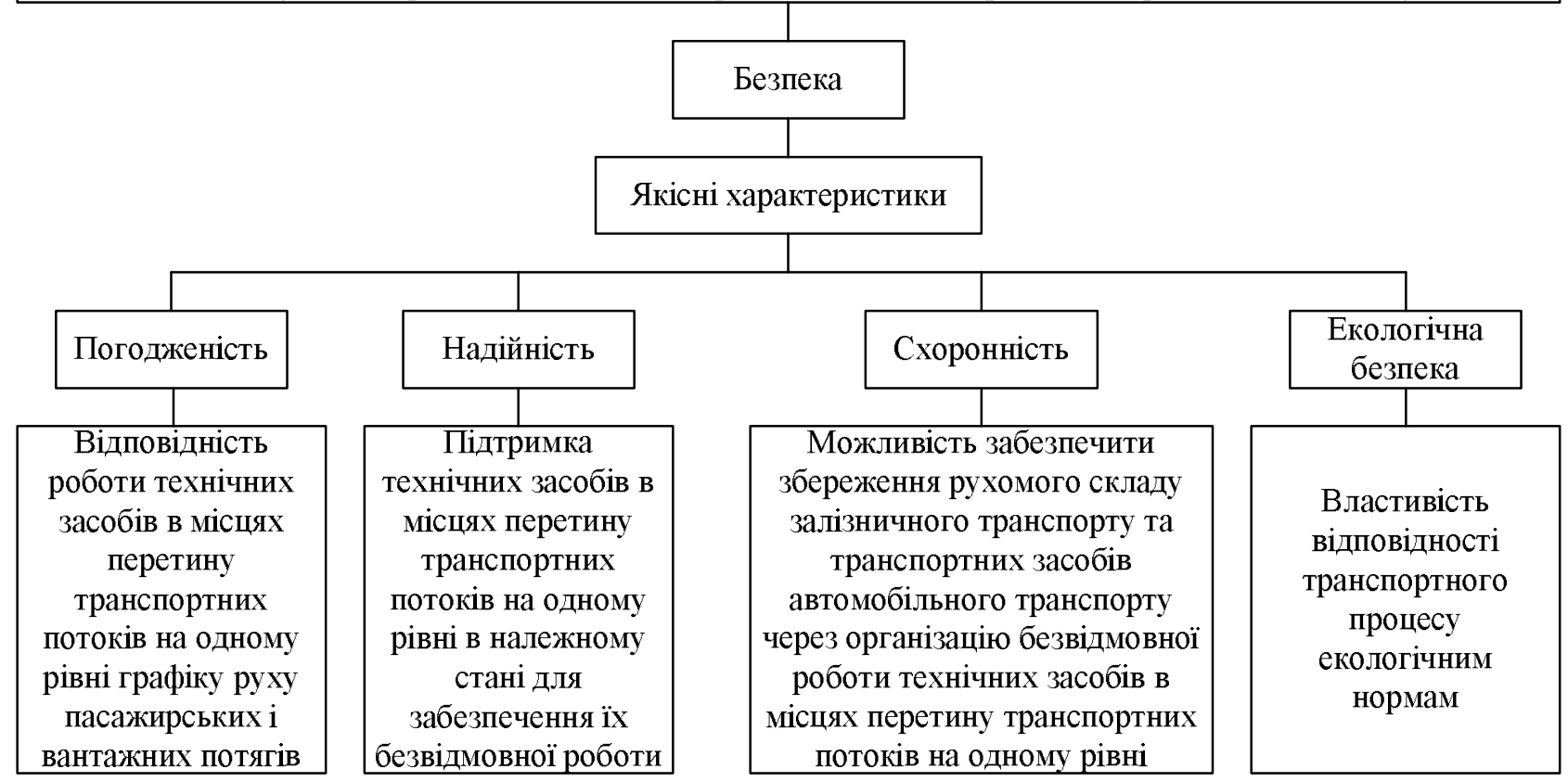

Рис. 1. Якісні характеристики транспортного обслуговування місцьь перетину транспортних потоків на одному рівні

3 техніко-технологічної точки зору безпеку транспортного обслуговування залізничних переїздів можна визначити як властивість залізничного транспортного комплексу не створювати небезпеку для здоров’я та життя пасажирів, технічного персоналу, людей, що перебувають у зоні залізничного транспортного процесу, а також створювати умови для збереження перевезеного вантажу, технічних засобів і навколишнього середовища.

Аналіз впливу стану технічних засобів, якими обладнанні місця перетину транспортних потоків на одному рівні, дозволив визначити основні характеристики їх впливу на якість та безпеку обслуговування транспортних потоків:
- технічні засоби традиційного обладнання залізничних переїздів мають недоліки, у результаті чого відбувається велика кількість дорожньо-транспортних подій та виникає велика кількість простоїв транспортних засобів. Це приводить до значних непоправних економічних втрат, морального збитку та, як результат, збільшення економічних ризиків клієнтів і зниження якості послуг залізничного й автомобільного транспорту;

- основною причиною технічної недосконалості засобів традиційного обладнання залізничних переїздів $\epsilon$ їх функціональна недостатність. У результаті цього близько 90\% ДТП в Україні стається 3 причин, яким технічні 
засоби в місцях перетину транспортних потоків на одному рівні, що наразі застосовуються, не можуть запобігти. Непродуктивні простої автотранспортних засобів за попередніми оцінками перевищують у 1,5-2 рази нормативні технологічні простої на залізничних переїздах.

На думку автора, найбільш діючим шляхом підвищення якості та безпеки транспортного обслуговування в місцях перетину транспортних потоків на одному рівні в умовах України $є$ розширення функціональних можливостей технічних пристроїв, якими обладнанні залізничні переїзди, за рахунок функцій, виконання яких спрямовано на попередження настання ДТП і зайвих простоїв автотранспортних засобів.

3 урахуванням вище викладено, для економічної оцінки якості та безпеки транспортного обслуговування місць перетину транспортних потоків на одному рівні пропонується застосовувати агрегатний підхід. Його особливістю $є$ врахування агрегатної структури технічних засобів, якими на даний час обладнані залізничні переїзди. При цьому агрегатна структура розглядається у вигляді сукупності технічних засобів, що складається 3 окремих пристроїв, кожний 3 яких виконує конкретну технологічну функцію та технічно інтегруються 3 іншими пристроями в єдину систему. Таким чином, економічна оцінка якості та безпеки транспортного обслуговування місць перетину транспортних потоків на одному рівні в умовах застосування агрегатного підходу виконується за кожним окремим пристроєм у складі технічних засобів, якими обладнанні залізничні переїзди.

Агрегатний підхід до питання економічної ефективності технічних засобів, якими обладнанні місця перетину транспортних потоків на одному рівні, доцільний як у теоретичному, так і у практичному плані.

У теоретичному плані при оцінці економічної ефективності технічних засобів, якими наразі обладнанні залізничні переїзди, запропонований підхід дозволяє:

- розробити критерії оцінки для визначення економічної ефективності існуючих і перспективних технічних засобів обладнання місць перетину транспортних потоків на одному рівні;

- здійснити вибір сукупності агрегатів, 3 яких мають бути складені технічні засоби залізничних переїздів, за критерієм найбільшої економічної ефективності для заданих умов експлуатації;
- визначити умови експлуатації місць перетину, при яких забезпечується економічно ефективне застосування різних сукупностей агрегатів технічних пристроїв обладнання місць перетину транспортних потоків на одному рівні.

У практичному плані агрегатний підхід до визначення рівня економічної ефективності технічних засобів, якими обладнанні залізничні переїзди, дозволяє:

- уникнути технічної надмірності при розробці та проектуванні технічного обладнання місць перетину транспортних потоків на одному рівні, що $є$ основою скорочення витрат на утримання й експлуатацію залізничних переїздів;

- модернізувати чи реконструювати технічні засоби обладнання місць перетину транспортних потоків при зміні умов експлуатації.

На думку автора, для оцінки економічної ефективності технічних засобів в місцях перетину транспортних потоків на одному рівні найбільш доцільно використовувати наступні показники економічної ефективності:

- сумарний за розрахунковий період економічний ефект від застосування технічних засобів транспортного обслуговування на залізничних переїздах;

- індекс прибутковості.

Автор вважає, що сумарний за розрахунковий період економічний ефект $\left(E_{T}\right)$ від застосування технічних засобів транспортного обслуговування на залізничних переїздах можна розрахувати за формулою

$$
E_{T}=\sum_{i=1}^{n} \sum_{t=1}^{T} R_{i}^{T}-\sum_{j=n}^{m} \sum_{t=1}^{T} Z_{j}^{T}
$$

де $R_{i}^{T}$ - сумарна вартісна оцінка результатів застосування функціонуючої або модернізованої (повністю зміненої) агрегатної структури технічних засобів, що складається 3 і-го виду пристроїв, у Т-му періоді;

$Z_{j}^{T}$ - сумарні витрати на виконання ј-го виду робіт 3 технічного оснащення, модернізації, реконструкції тощо місць перетину транспортних потоків на одному рівні в Т-му періоді;

$T$ - розрахунковий період.

Оскільки роботи 3 технічного оснащення, модернізації, реконструкції тощо місць перетину транспортних потоків на одному рівні та 3 їх транспортного обслуговування відбуваються на протязі тривалого періоду часу, то результати та витрати 3 цих робіт також отримуються на 
протязі всього періоду функціонування технічних засобів.

Відповідно до цього необхідно застосувати коефіцієнт приведення $\alpha_{t}$, який дозволить усунути тимчасову незіставність різноперіодних результатів i витрат. Для його розрахунку використовується формула

$$
\alpha_{t}=\frac{1}{\left(1+\frac{r}{100}\right)^{t}},
$$

де $r$ - ставка приведення різноперіодних доходів i витрат до початкового року, що визначається як середньозважена вартість капіталу, який використовується для фінансування робіт 3 технічного оснащення, модернізації, реконструкції тощо залізничних переїздів;

$$
t \text { - рік приведення }(t=1,2, \ldots, T) \text {. }
$$

Визначення ставки приведення різноперіодних витрат через застосування середньозваженої вартості капіталу дозволяє врахувати можливості по залученню кредитних ресурсів у разі нестачі власних коштів підприємства.

Таким чином, сумарна вартісна оцінка результатів застосування функціонуючої або модернізованої (повністю зміненої) агрегатної структури технічних засобів, що складається 3 iго виду пристроїв, у Т-му періоді буде розраховуватися за формулою

$$
R_{i}^{T}=\sum_{i=1}^{m} R_{i}^{t} * \alpha_{t}
$$

де $R_{i}^{t}$ - вартісна оцінка результатів застосування і-го виду пристроїв, що входять до складу функціонуючої або модернізованої (повністю зміненої) агрегатної структури технічних засобів обладнання залізничних переїздів, у t-му періоді.

У свою чергу, сумарні витрати на виконання ј-го виду робіт 3 технічного оснащення, модернізації, реконструкції тощо місць перетину транспортних потоків на одному рівні в Т-му періоді розраховуватимуться за формулою

$$
Z_{j}^{T}=\sum_{j=1}^{m} Z_{j}^{t} * \alpha_{t}
$$

де $Z_{j}^{t}$ - витрати на виконання ј-го виду робіт 3 технічного оснащення, реконструкції тощо місць перетину транспортних потоків на одному рівні в t-му періоді.

Відповідно до теорії оцінки ефективності інвестиційних та інноваційних проектів індекс прибутковості (IP) застосування технічних засобів транспортного обслуговування на залізничних переїздах визначається за наступною формулою

$$
I P=\frac{\sum_{i=1}^{n} \sum_{t=1}^{T} R_{i}^{T}}{\sum_{j=1}^{m} \sum_{t=1}^{T} Z_{j}^{T}} .
$$

Отже, найважливішими, на думку автора, показниками оцінки економічної ефективності технічних засобів в місцях перетину транспортних потоків на одному рівні $\epsilon$ показники сумарного за розрахунковий період економічного ефекту від застосування технічних засобів транспортного обслуговування на залізничних переїздах та індексу прибутковості, значення яких повністю залежить від функціонуючої агрегатної структури технічних засобів та змінюється при виконанні робіт 3 їх технічного оснащення, модернізації, реконструкції тощо.

Оскільки оцінку економічної ефективності технічних засобів в місцях перетину транспортних потоків пропонується виконувати за агрегатним підходом, то використання даних показників дозволить визначити вплив кожного із окремих пристроїв, які виконують конкретну технологічну функцію та технічно інтегруються 3 іншими пристроями в єдину систему технічних засобів на залізничних переїздах Саме це, на думку автора, дозволить врахувати якість та безпеку транспортного обслуговування в місцях перетину транспортних потоків на одному рівні.

Висновок 3 даного дослідження та перспективи подальших робім у цьому напрямку. Таким чином, аналіз особливості транспортного обслуговування місць перетину транспортних потоків на одному рівні свідчить про те, що проблема безпеки й якості транспортного обслуговування залізничних переїздів $є$ складною транспортною проблемою, що, крім соціальних, має яскраво виражені економічні аспекти. Дослідження цих аспектів дозволяє підсилити вплив економічних методів на обгрунтування технічної політики в сфері обладнання місць перетину транспортних потоків на одному рівні з позицій забезпечення якості та 
безпеки транспортного обслуговування.

Виходячи 3 критеріїв якості та безпеки транспортного обслуговування залізничних переїздів, запропоновано застосування агрегатного підходу до визначення їх економічної ефективності. Його особливістю $є$ врахування агрегатної структури технічних засобів, якими на даний час обладнані залізничні переїзди. А тому економічна оцінка якості та безпеки транспортного обслуговування місць перетину транспортних потоків на одному рівні в умовах застосування агрегатного підходу виконується за кожним окремим пристроєм у складі технічних засобів, якими обладнанні залізничні переїзди. Вибір саме агрегатного підходу грунтується на його теоретичні та практичній цінності.

Перспективи подальших досліджень у даному напрямку стосуються розробки математичного інструментарію для виконання оцінки ефективності технічних засобів транспортного обслуговування залізничних переїздів.

\section{СПИСОК ЛІТЕРАТУРИ}

1. Абрамов И.М. Внетранспортный эффект работы железных дорог / И.М. Абрамов, В.Г. Галабурда // Железнодорожный транспорт. 2012. - №3. - С. 58-62.

2. Волков Б.А. Эколого-экономическая оценка последствий аварийных ситуаций с опасными грузами / Б.А. Волков, И.С. Лобанова // Экономика железнодорожного транспорта. 2012. - №11. - C. 103-104.
3. Гибшман А.Б. Определение экономической эффективности проектных решений на железнодорожном транспорте / А.Б. Гибшман. - 5-е изд., перераб. и доп. - М.: Транспорт, 2005. - 240 с.

4. Дикань В.Л. Система інтегрованого управління інвестиційно-інноваційним розвитком залізничного транспорту / ВЛ. Дикань , О.Г. Кірдіна // Маркетинг і менеджмент інновацій. - 2011. - №1. - С. 137-144.

5. Ивлев И.В. Финансы и финансирование железнодорожного транспорта / И.В. Ивлев. - 8-е изд., перераб. и доп. - М.: Транспорт, 2010. $488 \mathrm{c}$.

6. Міщенко С.П. Економічна безпека залізничного транспорту України в контексті захисту національних інтересів країни / С.П. Міщенко // Вісник економіки транспорту i промисловості: збірник науково-практичних статей. - 2014. - №48. - С. 43-50.

7. Пасічник B.I. Економіко-організаційні аспекти управління експлуатаційною діяльністю залізниць / B.I. Пасічник // Залізничний транспорт України. - 2005. - №2. - С. 78-80.

8. Чередниченко О.Ю. Систематизація факторів впливу на економічну безпеку залізничного транспорту // О.Ю. Чередниченко // Вісник економіки транспорту і промисловості: збірник науково-практичних статей. - 2014. №48. - C. 73-78.

9. Thies H. Das FSS-Pilotprojekt der SBB weltweit erste Applikation von ETCS Level 2 / H. Thies, A. Wik // Signal and Draht. - 2012. - №9. P. 16-18.

Рецензент д.е.н., професор УкрДУЗТ Кірдіна О.Г. Експерт редакційної колегії к.е.н., дочент УкрДУЗТ Токмакова І.В.

УДК: 656.61(477):005.44

\title{
ФАКТОРЫ РАЗВИТИЯ НАЦИОНАЛЬНЫХ МОРСКИХ ТРАНСПОРТНЫХ СИСТЕМ НА СТАДИИ ГЛОБАЛИЗАЦИИ
}

\author{
Голубкова И.А., д.э.н., доцент, профессор (ОНМА)
}

\begin{abstract}
Формирование современной морской транспортной индустрии обусловлено трансформачионными процессами в системе международного разделения труда. Динамичность этого процесса становится важнейшим фактором развития морского транспортного потенциала. При этом существенно изменяется характер сбалансированности величины грузопотоков $u$
\end{abstract}

